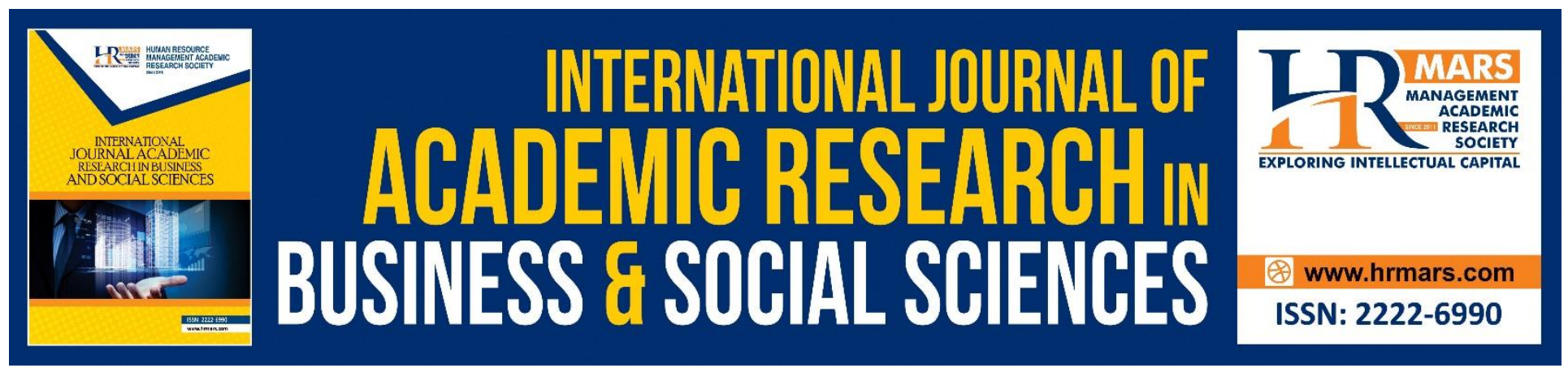

\title{
Risk Management Effectiveness Index Score for Pre and Post Malaysian Code on Corporate Governance 2012
}

Norfadzilah Rashid, Siti Nasuha Muhmad, Mohd Hassan Che Haat, Siti Nurain Muhmad, Hafiza Aishah Hashim, Asyraf Afthanorhan

To Link this Article: http://dx.doi.org/10.6007/IJARBSS/v8-i12/5068 DOI: $10.6007 /$ IJARBSS/v8-i12/5068

Received: 22 Oct 2018, Revised: 09 Dec 2018, Accepted: 26 Dec 2018

Published Online: 29 Dec 2018

In-Text Citation: (Rashid et al., 2018)

To Cite this Article: Rashid, N., Muhmad, S. N., Haat, M. H. C., Muhmad, S. N., Hashim, H. A., \& Afthanorhan, A. (2018). Risk Management Effectiveness Index Score for Pre and Post Malaysian Code on Corporate Governance 2012. International Journal of Academic Research in Business and Social Sciences, 8(12), 729741.

Copyright: (C) 2018 The Author(s)

Published by Human Resource Management Academic Research Society (www.hrmars.com)

This article is published under the Creative Commons Attribution (CC BY 4.0) license. Anyone may reproduce, distribute, translate and create derivative works of this article (for both commercial and non-commercial purposes), subject to full attribution to the original publication and authors. The full terms of this license may be seen

at: http://creativecommons.org/licences/by/4.0/legalcode

Vol. 8, No. 12, 2018, Pg. 729 - 741

http://hrmars.com/index.php/pages/detail/IJARBSS

JOURNAL HOMEPAGE

Full Terms \& Conditions of access and use can be found at http://hrmars.com/index.php/pages/detail/publication-ethics 


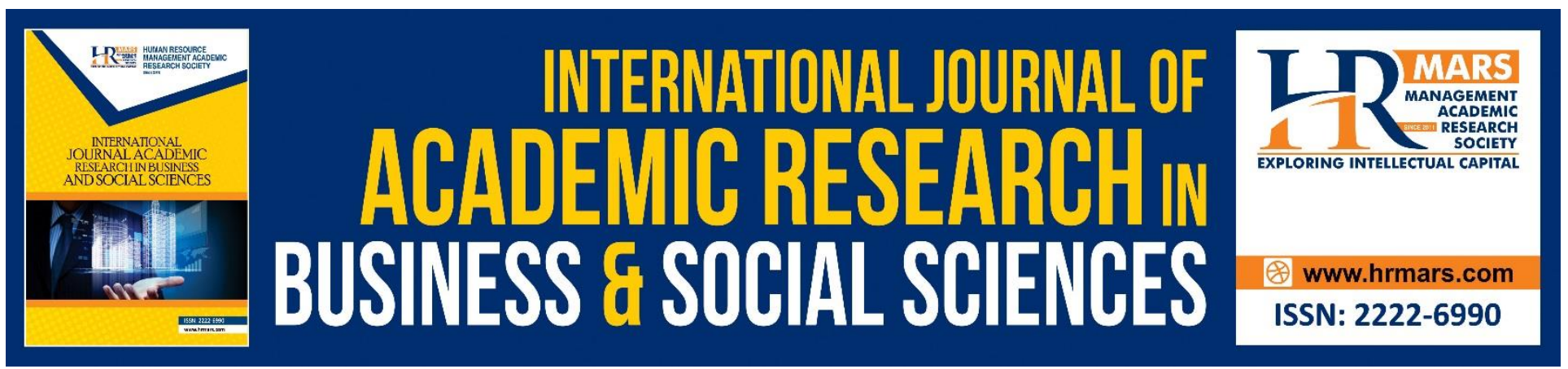

\title{
Risk Management Effectiveness Index Score for Pre and Post Malaysian Code on Corporate Governance 2012
}

${ }^{1}$ Norfadzilah Rashid, ${ }^{2}$ Siti Nasuha Muhmad, ${ }^{3}$ Mohd Hassan Che Haat, ${ }^{4}$ Siti Nurain Muhmad, ${ }^{5}$ Hafiza Aishah Hashim, ${ }^{6}$ Asyraf Afthanorhan

${ }^{1,6}$ Faculty Economics \& Management Science, Universiti Sultan Zainal Abidin, Malaysia

2,3,4,5School of Maritime Business and Management, Universiti Malaysia Terengganu, Malaysia

Corresponding Author: nikmfadzilah@unisza.edu.my

\begin{abstract}
Risk is the main issues, which is cause of uncertainty in any organisation. It's become a top priority for the international business community and the companies began focus on identify and manage risk before it affect the business. Malaysia has established and improves the corporate governance code, which is Malaysia Code on Corporate Governance 2012 and one of the principle discuss is to strengthen the risk management among the companies listed on Bursa Malaysia. There is a limited study on risk management effectiveness of the companies in Malaysia especially in developing the index for each sectors or industries. The main objective of this study is to develop the risk management effectiveness index for companies listed on the Main Board of the Bursa Malaysia in order to measure the commitment of companies towards risk management. An assessment questionnaire has been employed in this study to measure the risk management disclosure in annual report. The overall findings of the risk management effectiveness index revealed that among seven sectors of companies, trading sectors get high scores on five items studied.
\end{abstract}

Keywords: Risk Management, Disclosure, Corporate governance

\section{INTRODUCTION}

Inside the most recent two decades, corporate governance issues have turned into a best need for the global business group (Hossain, 2007). Accounting scandals by companies like Enron, WorldCom, Tyco, Swissair, Vivendi, Daewoo and Adelphia (Hossain, 2006) have created awareness among public about the weaknesses of corporate governance practices. Malaysia too has not been exempted from experiencing the collapse and loss of big companies such as Perwaja Steel, Omega Securities and Transmile (Wan Ismail, 2009) whose corruption included making unauthorised payments, arranging 
off-market transactions through several margin accounts, and submitting false information to the Bursa Malaysia Listing Requirements.

One of the corporate governance issues is risk management. Enterprise Risk Management (ERM) is a new trend in risk management, which became a global issue including in Malaysia. The Principle 6 in MCCG 2012 states that the board should establish a sound risk management framework and internal audit function. The Code highlights that the board should identify, assess, and monitor business risks to safeguard shareholders' investments and the company's assets. The Code recommends that that the board should establish a sound framework to manage risks and establish an internal audit function, which reports directly to the audit committee.

The revision of MCCG, which was announced by the Prime Minister of Malaysia in the Budget 2008 speech, is pointed at fortifying the board of directors and audit committees as well as guaranteeing that the board of directors and audit committees release their roles viably. Even though MCCG has been implemented since 2000, it still cannot effectively curb the irregular activities of certain directors.

Due to the corporate scandal that involves Linear Corporation Berhad in 2008, and Kenmark Industrial Co Ltd and Sime Darby in 2010, MCCG in Malaysia highlighted for the revision of MCCG 2007 to improve the poor performance of MCCG heretofore (Satkunasingam et al., 2012). Accordingly, the Securities Commission (SC) of Malaysia issued the Corporate Governance Blueprint document in July 2011 to improve the governance structure of the country, which facilitated the introduction of the MCCG 2012 in March 2012. MCCG 2012 is aimed at strengthening the boards and all committees to perform their duties effectively, to ensure that they present the timely and balanced disclosure, focus the vitality of risk management and internal controls, and safeguard the integrity of financial reporting.

Recognising the importance of corporate governance and in response to the MCCG 2012, it is vital to have a study focusing on the effectiveness of risk management in mitigating earnings management. Prior study such as Liebenberg \& Hoyt (2003) and Pagach \& Warr (2010) used appointment of Chief Risk Officer as a base for the initiation of the risk management program. Since there is limited study in Malaysia using an index as a measurement for risk management effectiveness, this study attempts to develop an index to rank which sectors have good risk management and internal control system in the organizations. Furthermore, MCCG 2012 also highlights that the board should establish a sound risk management framework and internal control system in the organizations. Thus, this study develops a risk management effectiveness index for the period before and after the revised MCCG in response to the Principle 6 of MCCG 2012. The end results of this study will enable investors, regulators, and other stakeholders to rank risk management practices among Malaysian companies.

\section{LITERATURE REVIEW}

Risks can be seen as a possible losses to the economic as well as financial gains, as a result of uncertainty associated with pursuit of action (Chapman \& Cooper, 1983). Every range of management of the company is risky and it is predictable based on experience and through human behavior. However, it can be manageable if it has a precautionary measure. Among the risk management tasks 
is identifying risks, the probability of risk that may occur, treating risks, reducing and subsequently eliminating the effects of that risks. Risk management is adopted in many areas such as enterprise management, healthcare, public safety and environment.

Enterprise risk management is a new concept that revolutionizes the traditional approach and summarizes risk management as an integrated, comprehensive and strategic system. The meaning of enterprise is to integrate all types of risks by using the tools and technique to mitigate the risks as well as to communicate across the business lines. According to Meulbroek (2002), integration can be explained by employing targeted financial instruments, modifying firm's operations and adjusting its capital structure.

Effective risk management intend to provide reasonable assurance to achieve the company's objectives and financial target (Mohammed \& Knapkova, 2016). The importance of risk management in the organization is also stated in the Principle 6 under MCCG 2012. The principles highlight the framework of risk soundness and internal control system in the company. According to the Code, the board should clearly mention the risk by identifying, assessing, and monitoring it in order to safeguard the company's assets and shareholder's investment.

There are another studies focus on the implementation of risk management programme in the organizations. Studies by Kleffner et al., (2003) employed about 336 respondents that primarily in charge of risk management in the respecting public listed company in Canada in 2001. The study expose that 37 companies adopted Enterprise Risk Management (ERM), 34 companies were investigating to adopt ERM and 47 companies were not practicing ERM. Additionally, the study found that there have 13 Chief Risk Officers (CRO) adopted ERM in 37 companies.

Prior study by Kleffner et al., (2003), Ahmad et al. (2015) and Daud et al., (2010) used CRO appointment as a base for the initiation of the risk management program. Furthermore, other studies were done before the revised MCCG in 2012. So, this study attempt to investigate whether there is an impact on the disclosure of the risk management by the companies listed in Bursa Malaysia Listing Requirements in the annual report after the establishment of the new clause under Principle 6 in MCCG 2012.

\section{RISK MANAGEMENT EFFECTIVENESS INDEX ATTRIBUTES}

This study uses risk management effectiveness index as a proxy for the initiation of the risk management which is different from the study by Pagach \& Warr (2010) that used Chief Risk Officer (CRO) appointment as a base for the initiation of the risk management program. A risk management effectiveness index is an indicator of the relative level to which an organization or a company follows the code and guidelines of risk management practices. The evaluation of risk management practices through the index score is important for depositors, investors and stakeholders of the companies in decision-making.

The model and indicators of the index developed in this study are taken from guidelines in Malaysian Code on Corporate Governance 2012 (MCCG 2012) and Committee of Sponsoring Organisations of the Tread way Commission (COSO) Framework. MCCG 2012 focuses on strengthening board structure and recognising the role of directors as active and responsible fiduciaries. As stated in the MCCG 2012, directors need to maintain an effective governance structure to ensure appropriate management of risks and level of internal controls. Listed companies required to report on their 
compliance of MCCG in their annual reports. The recommendation under principle 6 in MCCG 2012 highlights that the board should have sound framework to manage risk and establish an internal audit functions, which reports directly to the audit committee. Thus, all listed companies' needs to have sound risk management framework and internal audit function in place.

\section{APPOINTMENT OF THE RISK MANAGEMENT COMMITTEE}

The first attribute for this score represents the appointment of risk management committee in order to establish a sound risk management framework. The appointment of the risk management committee is an important element as the committee reviews the effectiveness of the risk management and control process in the company to present to the audit committee.

MCCG 2012 states that the board should establish a sound framework to manage risk. The risk management committee is appointed by the accounting officer to review the company's system of risk management and to establish a sound framework to manage risks. Thus, this attribute is based on the recommendations in MCCG 2012 that has been formulated to reflect the importance of having risk management committee in place.

\section{RISK MANAGEMENT FRAMEWORK}

Risk management framework is the structure within organisation that supports the risk management practices in all levels of organisation. MCCG 2012 focus on establishing the framework of sound risk management. The risk management framework is a description of streams of accountability and reporting that will support the risk management process. The risk management framework is used to identify the key risk management activities. The framework can be applied in all phases of the system development lifecycle such as in the acquisition, development, and operation cycle.

\section{MEETING OF RISK MANAGEMENT COMMITTEE}

Meeting of risk management committee is an essential element to have good risk management practices in the organization as it is the time for them to review the risk management framework, discuss, and clear representations about risk management practice in the organisation to the audit committee. The risk management committee should meet often, preferably two weeks before the audit committee meetings.

\section{RISK MANAGEMENT ACTIVITIES}

The risk management committee will construct the risk management activities using their knowledge and expertise. Among the risk management activities are communicating the objectives of the organisation, determining the risk appetite of the organisation, identify the risk that act as a threats to the accomplishment of the organisation's objectives and responses to the potential risk that have been assessed. Successful risk management in firms should have detailed risk management activities in place.

\section{STATEMENT ON INTERNAL CONTROL AND RISK MANAGEMENT}

Principle 6 of MCCG 2012 states that the board should disclose in the annual report the main features of the company's risk management framework and internal control system. The establishment of the 
statement on internal control and risk management shows that companies have risk management practices in place, instead of only focusing on the internal control system. After MCCG 2012, most companies listed in Bursa Malaysia changed the reporting statement from statement on internal control to statement on internal control and risk management. This action shows that companies are alert and take into considerations the requirements entailed in MCCG 2012.

In the statement, the board should highlight the effectiveness and disclose that there is an on-going process for identifying, evaluating, and managing the principal risks faced by the company.

\section{INTERNAL AUDIT DEPARTMENT}

The internal audit department is established to support the board through the board of audit committee. Principle 6 of MCCG 2012 states that the board should establish an internal audit function and identifies a head of internal audit that reports directly to the audit committee. As stated in COSO Framework, the effectiveness of the internal control in an organisation depends on the role of internal auditors in evaluating the internal control systems. There are certain benefits of having in house audit department rather than outsource the internal audit function to other auditor. The benefits include the members of the internal audit department have better understanding about the culture of the organisation, risks and challenges that face the organisations, which is useful in decision making. Internal auditing is an effort in line with the management of the organisation toward corporate governance and contributes to the long run success of the company. Therefore, it is appropriate to keep an in house internal audit. Besides that, the external auditors will not know the business as well as an internal audit department.

\section{INTERNAL CONTROL ACTIVITIES}

The reliability and efficiency of financial reporting is also depends on the internal control of the firm. Internal control also will ensure the smoothness of the firm operation which compliance with applicable laws and regulations. Based on COSO Framework, there have policies and procedures in control activity that could help to carry out the management directives. Establishing internal control can help companies to take necessary actions to reduce potential risk that may obstruct the achievement of company's objectives. The important parts in internal control involve separation of duties, adequate recorded of document, proper authorization for each activity in company and independent checks on performance.

\section{ROLE OF THE AUDIT COMMITTEE IN THE FUNCTIONING OF INTERNAL CONTROL SYSTEM}

The other risk management effectiveness index addresses the role of the audit committee in the internal control system. The audit committee is responsible for ensuring management maintains an adequate internal control system. According to Haron et al. (2010), the key oversight mechanism on internal control in publicly traded companies is the audit committee. The audit committee is responsible for the evaluation of the integrity of the internal monitoring and risk management system of the company (MCCG, 2001). 


\section{REFERENCES MADE TO AN ESTABLISHED CODE, COSO}

This attribute aims to assess whether firms employ international policy reports, such as COSO, in the organisation of their internal control system. The COSO framework is used to monitor risk management and internal control systems of the companies. According to the COSO framework, everyone in the organisations is responsible for reporting problems in operations and other illegal actions. The COSO framework consists of five components, which is control environment, risk assessment, control activities, information and communication, and lastly monitoring activities.

\section{REVIEW OF STATEMENT ON RISK MANAGEMENT AND INTERNAL CONTROL BY EXTERNAL AUDITORS}

This index measures the role of the external auditor in the system of internal control. coso Framework states that the external auditor may contribute to the evaluation of the system of internal control. COSO acknowledges the potential value the external auditor may contribute to the evaluation of the system of internal control. Others include highlighting the points for improvement, gaps and quality assessments, besides commenting about the risks of the company.

\section{METHODOLOGY}

\section{SAMPLE SELLECTION}

The sample of this study consists of the companies listed on the Main Board of the Bursa Malaysia for four years period from 2010 to 2013. The category of firms include in this study are taken form Bursa Malaysia which is excluding the finance category. It is consistent with Hashim \& Devi (2008) who find finance category, which is banks, insurance and unit trust firms have different statutory requirements and are excluded from the sample size. Additionally, the firms also have a complex and different working capital structure (Klein, 2002).

This study employed stratified random sampling (Uma Sakaran, 2003), which involves a process of stratification, followed by random selection of companies from each industry. The sample was selected using a random number generator to derive 1040 random numbers for four years. The breakdown of the sample size based on each industry using a table in determining sample size for research activities (Krejcie \& Morgan, 2007) is as follows:

Table 1: The Sample Companies Based on Industrial Sector

\begin{tabular}{|c|c|c|c|}
\hline No & Industrial sector & Number of companies & Sample size \\
\hline 1 & Construction & 50 & 16 \\
\hline 2 & Consumer products & 140 & 45 \\
\hline 3 & Industrial products & 265 & 80 \\
\hline 4 & Plantation & 42 & 15 \\
\hline 5 & Properties & 85 & 35 \\
\hline 6 & Technology & 30 & 10 \\
\hline 7 & Trading/services & 181 & 59 \\
\hline & Total & $\mathbf{7 9 3}$ & $\mathbf{2 6 0}$ \\
\hline
\end{tabular}




\section{DATA COLLECTION}

This study employed the secondary data, which adopts the content analysis approach. The evaluation is based on the disclosure in the annual report for each company. Many academicians have used the annual reports as a tool for obtaining information from the firms. Che Haat (2006) agreed that the annual reports should provide a useful medium to present the voluntary disclosure provided by a firm. The analysis for this study involves 260 companies from 2010 to 2013.

\section{MEASUREMENT}

This study evaluated risk management effectiveness index using an assessment questionnaire based on a "yes" or "no". It is similar to the studies by Darmadi (2011), Gowd, Kiran \& Rao (2010) and Haniffa \& Hudaib (2004) which is used the "yes" or "no" options that adopt from the Minority Shareholder Watchdog Group Report (2009/10/11).

In this study, when companies did not disclose at all in the annual reports the attributes measured, the score is " 0 " and the score of " 1 " is given when companies gives information about the risk management guidelines.

\section{RESULT}

\section{ASSESSING THE VALIDITY AND RELIABILITY OF DISCLOSURE SCORE}

Reliability is the extent to which measures are tested and produce consistent results. The reliability test should be employed in this study since this study implemented the risk management index to prove that it is free form random errors and internal consistency. Boyle \& Radocy (1987) used Kuder Richardson's formula to analyse tests with dichotomous items. The Kuder Richardson 20 (KR20) is a special case of Cronbach's Alpha in which the items are binary variables. The range value of KR20 should between 0 to 1 . Better internal consistency present the value that closer to 1 . To acquire the reliable score; the result should attempt the reliability coefficient of 0.7 and above Fraenkel \&Wallen (2008). According to Wells \& Wollack (2003), the reliability test should have internal consistency coefficients of at least 0.9. However, according to Nunnally (1978), 0.7 is acceptable reliability coefficient and can be used to prove that the data is reliable for this study. The index used in this study consists of ten attributes and 1040 items in total. The result of the reliability test (not reported), the KR20 value was 0.897 and is thus above the 0.7 minimum level recommended by Nunnally (1978).

\section{OVERALL SCORES}

Table 2 presents the composition of risk management effectiveness index. The index comprises 10 variables. For each variable, a score of " 1 " is the score given when the companies complied and disclosed details of such compliance accordingly. If an item was not disclosed, it was marked as " 0 ". The maximum score the company can obtain is $10.59 \%$ of the companies complied with the risk management index tested (610 out of 1040). 
INTERNATIONAL JOURNAL OF ACADEMIC RESEARCH IN BUSINESS AND SOCIAL SCIENCES

Vol. 8, No. 12, Dec, 2018, E-ISSN: 2222-6990 @ 2018 HRMARS

Table 2: Mean score for Risk Management Effectiveness Index Based on Industries and Period

\begin{tabular}{ccc}
\hline \multirow{2}{*}{ Industries } & \multicolumn{2}{c}{ Mean Score (\%) } \\
\cline { 2 - 3 } & Pre period & Post period \\
\hline Construction & 34 & 69 \\
\hline Consumer & 44 & 81 \\
\hline Industrial & 29 & 67 \\
\hline Plantation & 40 & 80 \\
\hline Properties & 39 & 83 \\
\hline Technology & 0 & 40 \\
\hline Trading & 65 & 88
\end{tabular}

The table show that the percentage score of the index for post revised MCCG period is higher than pre revised MCCG period. The results imply that every industry shows an increment in the effectiveness of risk management after the establishment of MCCG 2012.

\section{RAW SCORES OF ATTRIBUTES}

The mean score from the attributes show which sectors get high scores and comply with the measured attributes.

Table 3: Mean Score for Risk Management Effectiveness Index

\begin{tabular}{cccc}
\hline No & Attributes & $\begin{array}{c}\text { Highest Mean } \\
\text { Score for Sectors }\end{array}$ & $\begin{array}{c}\text { Mean Score } \\
(\%)\end{array}$ \\
\hline 1 & Appointment of Risk Management & Pommittee & 67 \\
\hline 2 & Risk Management Framework & Trading & 83 \\
\hline 3 & Meeting of Risk Management Committee & Trading & 42 \\
\hline 4 & Risk Management Activities & Plantation & 100 \\
\hline 5 & Statement on Internal Control and Risk & Technology & 43 \\
\hline 6 & Management & Consumer & 87 \\
\hline 7 & Internal Audit Department & All Except & 100 \\
\hline 8 & Role of the Audit Committee in the & Plantation & 100 \\
& functioning of ICS & & 9 \\
\hline 9 & References Made to an Established Code & Trading & \\
\hline 10 & Review of Statement on Internal Control & Trading & \\
\hline & and Risk Management by External Auditors & & \\
\hline
\end{tabular}


The first attribute represents the appointment of risk management committee or the person in charge of risk management. The risk management committee is an important element in the risk management process as they run the risk management system and lead the risk management programme. Table 3 showed that the highest score for appointment of the risk management committee is from the plantation sector. This means that $67 \%$ (40 out of 60 ) of companies from the plantation sector disclosed the attributes and $33 \%$ of the companies from the construction sector did not disclose the attributes in the annual report.

The second attribute is the establishment of the risk management framework. The framework is important because it identifies the key risk management activities and helps improve risk management practices. From Table 3, the highest mean score is from the trading sector with $83 \%$ (195 out of 236). The figure shows that most companies selected from the trading sector have a risk management framework in place.

The third attribute is the meeting of the risk management committee. The highest score is from the trading sector with $42 \%$ (98 out of 236). It shows that companies from the trading sector have complied with the rule that the risk management committee should meet at least as often preferably two weeks before the audit committee meetings to review, discuss and clear representations that will be made to the audit committee.

The fourth attribute is risk management activities. The risk management committee will construct the risk management activities and a successful risk management in firms should have detailed risk management activities in place. Based on Table 3, the plantation sector received $100 \%$ score that implies all companies selected from this sector have risk management activities in place.

The fifth attribute is establishment of the Statement on Internal Control and Risk Management. Technology sector had the highest mean score with $43 \%$. It shows that companies from this sector have risk management practices in place instead of only focusing on the internal control system.

The establishment of the internal audit department is an important element as it is responsible for assessing the operation of the internal control system and for making recommendations to improve it. Table 3 shows that the highest score for this attribute is from the consumer sector with $87 \%$. The results indicate that most of the companies in the consumer sector have an in house internal audit department. Others have outsourced the internal audit function to the other auditors.

The sixth attribute is internal control activities. Companies need to have internal control activities in place so that uncertainties, loss and theft can be reduced and prevented. Based on Table 3, most of the sectors scored $100 \%$ except for construction sector with $88 \%$. This shows that most of the companies listed on Bursa Malaysia have internal control activities in place.

The seventh attribute is the role of the audit committee in the functioning of the internal control system. The highest score is from the plantation sector with $100 \%$. This means that all companies listed in the plantation sector have an audit committee involved in the functioning of the internal controls.

The next attribute is references made to the established code, namely cOSO. The COSO Framework is used to monitor risk management and internal control systems of the companies. The highest score is from the trading sector with $9 \%$. This implies that only a few companies have made reference to an established international framework in the functioning of internal controls. As stated earlier, the cOSO Framework is used to monitor risk management and internal control systems of the companies 
and it is important for companies to comply with the framework. In this study, the trading sector scored the highest possibly because companies in the trading sector are involved in high volumes of inventory. Therefore, it is important for the companies to follow the COSO Framework as the framework highlights five components, which are control environment, risk assessment, control activities, information and communication, and lastly monitoring activities to monitor the internal and risk management in the organisation.

The last attribute is review of Statement on Internal Control and Risk Management by the external auditors. The external auditor contributes as they evaluate the system of internal control in the organisation. The highest mean score is from trading sector, which is $64 \%$. This means that, in the trading sector, the external auditors contribute to the evaluation of the system on internal control and risk management as the external auditors highlight the points for improvement, gaps and quality assessments, in addition to comments about the risks of the company.

\section{DISCUSSION AND CONCLUSION}

The attributes have been measured to reveal their contribution and the importance of risk management effectiveness index scores in this study. A higher score proves that firms have complied with the requirements of related guidelines. The results show that firms have sought to enhance their risk management practices. From the score, the plantation sector scores highest for most of the variables examined. This could be due to this sector is one of Malaysia's major exports earnings. Due to strong global demand, the sector needs to have a proper internal control system and management of risks to reduce inefficiency and wastage. Overall results illustrate that the score of risk management effectiveness index for post period is bigger than pre period. This showed that the Securities Commission has imposed proper recommendations by requiring the board to have a proper risk management framework and internal control system in the organisation.

The findings of this study are important since it will benefit the government and regulatory bodies such as the Securities Commission, Minority Shareholders Watchdog Group (MSWG), Audit Oversight Board (AOB), Bursa Malaysia and the Malaysian Institute of Corporate Governance (MICG), in developing new policies, procedures or guidelines, as well as in improving the rules pertaining to corporate governance as well as risk management.

\section{REFERENCES}

Ahmad, R. A. R., Abdullah, N., Jamel, N. E. S. M., \& Omar, N. (2015). Board Characteristics and Risk Management and Internal Control Disclosure Level: Evidence from Malaysia. Procedia Economics and Finance, 31(2011), 601-610. https://doi.org/10.1016/S2212-5671(15)01147-8

Boyle, J. D., \& Radocy, R. E. (1987). Measurement and evaluation of musical experiences. MacMillan Publishing Company.

Casualty Actuarial Society Enterprise Risk Management Committee. (2003). Overview of Enterprise Risk Management. Fairfax, VA: Casualty Actuarial Society.

Chapman, C. B., \& Cooper, D. F. (1983). Risk Engineering: Basic Controlled Interval and Memory Models. Journal of the Operational Research Society, 51-60.

Che Haat, M.H. (2006b). The Effect of Corporate Governance on Transparency and Performance of Malaysian Companies.(PhD Thesis), University Teknologi Mara. 
Darmadi, S. (2011). Board diversity and firm performance: the Indonesian evidence. Corporate ownership and control Journal, 8, 524

Daud, W. N. W., Yazid, A. S., \& Hussin, H. M. R. (2010). The Effect of Chief Risk Officer (CRO) on Enterprise Risk Management (ERM) Practices: Evidence from Malaysia. The International Business \& Economics Research Journal,9(11), 55.

Fraenkel, J. R., Wallen, N. E., \& Hyun, H. H. (1993). How to design and evaluate research in education (Vol. 7). New York: McGraw-Hill

Gowd, T.N., Kiran, C.B., \& Rao, C.R.P. (2010). Empirical Study on Corporate Governance Practices in State Bank of India Journal of Research in Commerce \& Management, 2(6).

Haniffa, R., \& Hudaib, M. (2004) 'Disclosure Practices of Islamic Financial Institutions: An

Exploratory Study', paper presented at the Accounting, Commerce and Finance: The

Islamic Perspective International Conference V, Brisbane, Australia, June 2004.

Haron, H., Daing Nasir Ibrahim, D., Jeyaraman, K., \& Hock Chye, O. (2010). Determinants of internal control characteristics influencing voluntary and mandatory disclosures: A Malaysian perspective. Managerial Auditing Journal, 25(2), 140-159

Hashim, H.A, Devi, S.S. (2008).

http://www.afaanz.org/openconffaanz2008/modules/request.php?module=oc_proceedings\&actio $\mathrm{n}=$ view.php\&a=Accept as Forum\&id=382. Accessed on 5 May 2010.

Hossain, M. (2007). The Corporate Governance Reporting Exercise: The Portrait of a Developing Country. International Journal of Business Research, 7(2), 106-118.

Kleffner, A. E., Lee, R. B., \& McGannon, B. (2003). The Effect of Corporate Governance on the Use of Enterprise Risk Management: Evidence from Canada. Risk Management and Insurance Review, 6(1), 53-73.

Klein, A. (2002). Audit Committee, Board of Director Characteristics, and Earnings Management. Journal of accounting and economics, 33(3), 375-400.

Krejcie, R. V., \& Morgan, D. W. (1970). Determining Sample Size for Research Activities. Educational and Psychological Measurement, 30, 607-610.

Liebenberg, A. P., \& Hoyt, R. E. (2003). The Determinants of Enterprise Risk Management:

Evidence from The Appointment Of Chief Risk Officers. Risk Management and Insurance Review, 6(1), 37-52.

Meulbroek, L. K. (2002). A Senior Manager's Guide to Integrated Risk Management. Journal of Applied Corporate Finance, 14(4), 56-70.

Mohammed, H. K., \& Knapkova, A. (2016). The Impact of Total Risk Management on Company's Performance. Procedia - Social and Behavioral Sciences, 220(March), 271-277. https://doi.org/10.1016/j.sbspro.2016.05.499

Nunnally, J.C. (1978). Psychometric Theory. New York: McGraw-Hill.

O'Sullivan, M., Percy, M., \& Stewart, J. (2008). Australian evidence on corporate governance attributes and their association with forward-looking information in the annual report.Journal of Management \& Governance, 12(1), 5-35.

Pagach, D., \& Warr, R. (2011). The characteristics of firms that hire chief risk officers.Journal of Risk and Insurance, 78(1), 185-211. 
Satkunasingam, E., \& Cherk, A. Y. S. (2012). The Influence of Cultural Values on the Board of Directors: Lessons from Five Corporations. Corporate Ownership \& Control Continued-2, 9(4), 221-229.

Sekaran, U. (2003). Research method for business: A skill building approach, 4th edition, John Wiley \& Sons.

Wells, C.S., \& Wollack, J.A. (2003). An Instructor's Guide to Understanding Test ReliabilityUniversity of Wisconsin Madison. 